\title{
Effects on Performance, Skin and Liver Histology of Different Clinoptilolite Levels in Rat Diets ${ }^{\#}$
}

\author{
Dilek Şentürk Demirel ${ }^{1 *}$, Ramazan Demirel ${ }^{1}$, Muzaffer Aydın Ketani² ${ }^{2}$ Kadri Balcı $^{3}$ \\ ${ }^{1}$ Department of Animal Science, Feeds and Animal Nutrition, Faculty of Agriculture, Dicle University, 21280 Diyarbakir, Turkey \\ ${ }^{2}$ Department of Histology and Embryology, Faculty of Veterinary, 21280 Diyarbakir, Turkey \\ ${ }^{3}$ Department of Biology, Faculty of Science, Dicle University, 21280 Diyarbakir, Turkey
}

\section{A R T I C LE I N F O}

\#This article was abstracted from a $\mathrm{PhD}$ thesis of Dilek Şentürk Demirel

\section{Article history:}

Received 10 July 2014

Accepted 02 October 2014

Available online, ISSN: 2148-127X

\section{Keywords:}

Clinoptilolite

Feed

Histology

Liver

Rat

Skin follicle

\section{A B S T R A C T}

The objective of this study was to test the effects of dietary natural zeolite (clinoptilolite) on performance, skin and liver histology in rats. In this study, 24 10-week-old, weaned, adult male Spraque-Dawley rats with approximately $306 \pm 18.93 \mathrm{~g}$ initial live weight were used. The rats were randomly divided into four groups with three replicates, including a control group and groups with one of three doses of clinoptilolite $(2 \%, 4 \%$, and $6 \%$ ) in their diets. All the rats were fed these concentrates throughout the experimental period of 56 days. The animals were reared individually in stainless steel cages. There were no significant differences in the primary and secondary follicle numbers among groups, but the diameters of each follicle were found to be significant. The primary and secondary follicle numbers and diameters ranged from lowest to highest as follows: $2.00-2.33,4.50-7.17$; and $11.53-20.42,57.63-102.12 \mu \mathrm{m}$, respectively. The differences occurred between the control group and group IV (containing 6\% zeolite). In addition, the skin and liver histology results showed that there were no differences among the groups.

\section{Rat Rasyonlarında Farklı Düzeylerde Klinoptilolit Kullanımının Performans, Deri ve Karaciğer Histolojisi Üzerine Etkileri}

\author{
M A K A L E B İ L G İ S İ
}

Geliş 10 Temmuz 2014

Kabul 02 Ekim 2014

Çevrimiçi baskı, ISSN: 2148-127X

\section{Anahtar Kelimeler:}

Klinoptilolit

Yem

Histoloji

Karaciğer

Rat

Deri folikülü

Sorumlu Yazar:

E-mail: senturk@dicle.edu.tr
Ö Z E T

$\mathrm{Bu}$ araştırma rat yemlerine ilave edilen doğal zeolitin (klinoptilolit) performans, deri ve karaciğer histolojisi üzerine etkilerini incelemek amacıyla yapılmıştır. Bu çalışmada, hayvan materyali olarak 24 adet on haftalık yaştaki, yaklaşık $306 \pm 18,93 \mathrm{~g}$ canlı ağırlığındaki sütten kesilmiş erkek yetişkin Spraque-Dawley rat kullanılmıştır. Ratlar tesadüf parselleri deneme desenine göre üçer tekerrürlü, 4 gruba (klinoptilolit içermeyen grup kontrol grubunu oluştururken, $\% 2, \% 4$, and $\% 6$ düzeylerinde klinoptilolit ilavesinin yapıldığı gruplar muamele gruplarını oluşturacak şekilde) rastgele dağıtılmıştır. Deneme 56 gün sürmüştür. Deneme bireysel paslanmaz çelikten yapılmış kafeslerde yürütülmüştür. Primer ve sekonder folikül sayıları bakımından gruplar arasında istatistiki olarak önemli düzeyde farklılık tespit edilmemekle beraber, her iki folikülün çap değerleri ise önemli bulunmuştur. Primer ve sekonder folikül sayıları ve çapları en yüksek ve en düşük değerler olarak sırasıyla 2,00-2,33; 4,50-7,17 ve 11,53-20,42; 57,63$102,12 \mu \mathrm{m}$, olarak tespit edilmiştir. Önemli düzeydeki farkl1lık control grubuyla, IV. grup (\%6 klinoptilolit içeren) arasında meydana gelmiştir. Ayrıca, derinin ve karaciğerin histolojik olarak incelenmesi sonucunda gruplar arasında önemli düzeyde farklılık tespit edilmemiştir. 


\section{Introduction}

Zeolites are important raw materials as alkali and alkaline earth cations sodium, potassium, calcium and magnesium containing elements such as water aluminocilicates. They have a 3-dimensional crystalline structure (Mumpton, 1999). They can selectively adsorb gas and steam molecules, reversibly adsorb and desorb water, based on ion selectivity, they can exchange their own cations for others (Melenova et al., 2003). Zeolites, as unconventional feed supplements may be recommended for the detoxification of the animal and prevention of diarrheal diseases in animals. They have been used in animal feed since the 1960 s, mainly to improve performance and to protect animals against mycotoxin hazards and industrial, agricultural and environmental pollution, in medical drug industry, and as mycotoxin binder adsorbents (Trckova et al., 2004).

The beneficial effects of natural zeolite may be related to its type, geographical source, purity, physicochemical properties and the supplemental level used in a diet (Pond et al., 1988). When they are used as a supplement in a diet, it binds toxins and heavy metals, and some nutrients in the fodder are adsorbed, providing more efficient feed consumption. Therefore, clinoptilolite has been proven to increase productivity at low cost when it is added to the feed of various farm animals. It has no adverse effects on animal welfare (Mayura et al. 1998) and health (Demirel et al. 2011; Eleroğlu et al. 2011). The addition of $0.5 \%$ clinoptilolite in the diets of pregnant rats did not affect the developmental parameters (embryonic resorption and foetal body weight) and did not cause any significant changes to body weight (Mayura et al. 1998). In a mouse diet, HSCAS (hydrated sodium calcium aluminosilicate) did not cause any changes in the kidney and liver histological pictures or animal health (Abbès et al., 2006a).

Many researchers have shown that the dietary inclusion of zeolites improves the average daily gain or feed conversion ratio in sheep, pig and dairy cows (Forouzani et al., 2004; Papaioannou et al., 2004; Katsoulos et al., 2006). Zeolites also enhance the reproductive performance of sows (Papaioannou et al., 2002), negatively affect the spermatozoon morphology of male rats (Taş et al., 2007), increase the milk yield of dairy cows (Katsoulos et al., 2006). The addition of 5\% zeolite in rat diets did not affect the growth and development of generation (Sorokina et al., 1995). According to some literature, dietary zeolite affects the sheep wool quality (Çolpan and Yalçın, 1986; Cobon et al., 1992; Walz et al., 1998), liver and kidney histology (Abdel-Wahhab, 2002; Abbès et al. 2006a), and liver pathology (Eraslan et al., 2006; Şehu et al., 2007). This study was performed to understanding animal follicle characteristics, skin and liver histology; in addition to feeding performance and toxin binding effects of clinoptilolite.

\section{Materials and Methods}

This study was approved by the animal ethics committee at Dicle University (protocol no: 2005/36, date: 19.04.2005).

\section{Zeolitic material}

Zeolite obtained from Manisa, Turkey, was used as the porous template medium. Clinoptilolite was the predominant mineral $(95 \%)$ in the natural zeolite. The chemical content and rates of clinoptilolite measured by an XRF spectrometer were as follows: $\mathrm{SiO}_{2}, \mathrm{CaO}, \mathrm{Fe}_{2} \mathrm{O}_{3}$, $\mathrm{Al}_{2} \mathrm{O}_{3}, \mathrm{~K}_{2} \mathrm{O}, \mathrm{MgO}, \mathrm{Na}_{2} \mathrm{O}, \mathrm{TiO}_{2}, \mathrm{MnO}$, LOI (lost on ignition), $\mathrm{SiO}_{2} / \mathrm{Al}_{3} \mathrm{O}_{2}$ as $65-72,2.5-3.7,0.8-1.9,10-12$, $2.3-3.5,0.9-1.2,0.3-0.65,0-0.1,0-0.08,9-12$, and 5.4$6.0 \%$ ), respectively (Anonymous, 2012). All the animals accepted and tolerated the zeolite-supplemented diets without problems.

\section{Feeds and feeding}

Rat compound feed was purchased from the Elazı $\breve{g}$ Mixed Feed Mill as powder form. In the feed unit of department, ground mixed feeds were prepared in pellet form with a special apparatus. Four different rations were prepared by adding zeolite at a weight of $0 \%$ (control), $2 \%, 4 \%$, and $6 \%$ of feed, respectively, to be iso-caloric (ME: $3200 \mathrm{kcal} / \mathrm{kg}$ ) and iso-nitrogenic (crude protein: $22.50 \%$ ). In order to get balanced copound feed, some feedstuffs (fish meal, soybean meal, molasses and vegetable oil) were added. The pelleted feed was kept in a drying cabin at $70^{\circ} \mathrm{C}$ for $12 \mathrm{~h}$. To maintain the dry matter content of all the feed, the water capacity of the feed was decreased to normal levels. When the water percentage of the feed was decreased enough (dry matter content : $>88 \%$ ), the feed was removed from the machine and returned to its respective bags after it was cooled and shortened to $2 \mathrm{~cm}$ long. Each experimental group received its specific diet ad libitum throughout the experimental period. The feedstuffs content and chemical compositions of the experimental diets are presented in Table 1.

\section{Animals and treatments}

In the study, 24 healthy adult male Sprague-Dawley rats (aged 8 weeks, average $307 \pm 19 \mathrm{~g}$ initial weight) were obtained from the Experimental Research Centre (DUSAM). The animals were housed individually under standard laboratory conditions (12-h light:12-h dark and $24 \pm 3^{\circ} \mathrm{C}$ ). Feed and water were provided ad libitum. The rats were randomly divided into four equal groups $(n=6)$ according to their dietary zeolite levels $(0 \%, 2 \%, 4 \%$, or $6 \%$ ). The control animals received the same feed without the zeolite. Live weight gain (LWG) and feed intake (FI) values were determined at weekly intervals, and feed conversion ratios (FCR) were determined by calculation.

FCR $=$ Total Feed Intake/ Total Live Weight Gain.

At the end of the experiment, all animals were anesthetized with sodium thiopental $(4 \mathrm{mg} / \mathrm{kg}$. body weight, i.p.; Ketalar, Pfizer) and sacrificed, and skin samples were taken abdominal tissue $(2 \times 2 \mathrm{~cm})$ of rats. Skin and liver samples were stabilized in $10 \%$ neutral formol (Sigma-Aldrich) for 18 hours. Then, samples were kept in absolute alcohol (Sigma-Aldrich) (100\%) and methyl benzoate (Sigma-Aldrich) for 3 days and a paraffin medium at $58^{\circ} \mathrm{C}$ for 3 hours. The blocked tissue samples were sliced using a rotary microtome (Leica RM2125RT, Germany) at a thickness of 4-5 $\mu \mathrm{m}$. The liver preparations were dyed with haematoxylin eosin and triple dye (Demir et al., 2001). 
Table 1 Constituents and chemical compositions of diets used in trial.

\begin{tabular}{|c|c|c|c|c|}
\hline \multirow[b]{2}{*}{ Feedstuffs } & \multicolumn{4}{|c|}{ Groups } \\
\hline & $\begin{array}{c}\text { I } \\
\text { Control }\end{array}$ & $\begin{array}{c}\text { II } \\
2 \% \text { Zeolite } \\
\end{array}$ & $\begin{array}{c}\text { III } \\
4 \% \text { Zeolite }\end{array}$ & $\begin{array}{c}\text { IV } \\
6 \% \text { Zeolite }\end{array}$ \\
\hline Rat concentrate feed $(\mathrm{g})$ & 755 & 702 & 660 & 610 \\
\hline Fish meal $(\mathrm{g})$ & 50 & 50 & 50 & 50 \\
\hline Soyben meal (g) & 40 & 63 & 80 & 100 \\
\hline Molasses (g) & 50 & 50 & 50 & 50 \\
\hline Vegetable oil (g) & 105 & 115 & 120 & 130 \\
\hline Clinoptilolite (g) & - & 20 & 40 & 60 \\
\hline Total $(\mathrm{g})$ & 1000.0 & 1000.0 & 1000.0 & 1000.0 \\
\hline \multicolumn{5}{|c|}{ Chemical Composition, $\%$} \\
\hline Dry Matter & 93.55 & 94.15 & 94.40 & 95.10 \\
\hline Crude Protein & 22.41 & 22.58 & 22.65 & 22.45 \\
\hline Ether Extact & 13.36 & 13.76 & 14.49 & 15.54 \\
\hline Ash & 8.05 & 9.10 & 10.02 & 10.40 \\
\hline Organic Matter & 85.50 & 85.05 & 84.38 & 84.70 \\
\hline Nit. Free Extract & 40.23 & 38.56 & 36.04 & 34.66 \\
\hline Crude Fiber & 9.50 & 10.15 & 11.20 & 12.05 \\
\hline Acid Detergent Fiber & 16.67 & 19.32 & 20.25 & 18.85 \\
\hline Neutral Detergent Fiber & 38.08 & 38.76 & 36.65 & 32.71 \\
\hline Energy, Kcal ME/kg * & 3203 & 3229 & 3211 & 3225 \\
\hline
\end{tabular}

*Calculated

In addition to these dyes, skin samples dyed to the Van-Gieson stained with hematoxylin were examined by light microscopy (Demir et al., 2001). The preparations were examined with a Nikon-Eclipse 400 (Japan-678382: code) photographic binocular apparatus. An ocular micrometer was used to determine the primary and secondary follicle numbers and diameters. Average 10 primary and secondary hair follicle diameters were measured in the skin samples of each rat.

\section{Statistical analysis}

The study was arranged according to a randomised plot design with four groups and three replicates. In the statistical comparisons between the groups, the one-way analysis of variance (ANOVA) was used. The significance controls of the differences between the groups were determined by the Duncan test (Duncan, 1955). The means for the data were calculated. All statistical analyses were carried out using the SPSS program v. 10.0 for Windows. The means and mean of standard errors (mean \pm S.E.M.) are presented in tables. $\mathrm{P}$ values $<0.05$ were accepted as statistically significant.

\section{Results and Discussion}

\section{Performance}

The total live weight gain (LWG), feed intake (FI), and feed conversion ratios (FCR) of the rats are presented in Table 2. There were no significant differences among the treatment groups for the LWG, FI, and FCR values $(\mathrm{P}>0.05)$.

\section{Live Weight Gain}

The highest total rat live weight gain was obtained in group I (control) at $53.00 \mathrm{~g}$, followed by group II $(2 \%$ clinoptilolite) at $49.75 \mathrm{~g}$, group III (4\% clinoptilolite) at $47.67 \mathrm{~g}$, and group IV (6\% clinoptilolite) at $45.92 \mathrm{~g}$. Our total LWG results are not in similar to the findings of Grosicki and Domanska (2000), Prvulović et al. (2007) and Alexopoulos et al. (2007). Increasing levels of clinoptilolite decreased feed nutrient contents (energy, protein etc.) and this forced feed intake and live weight gain.

\section{Feed Intake}

The highest individual total feed intake was obtained for group III at $1011.58 \mathrm{~g}$, followed by group II at $998.58 \mathrm{~g}$, group I at $988.75 \mathrm{~g}$, and group IV at $971.83 \mathrm{~g}$. Our FI results are similar to the findings of Malagutti et al. (2002), Wiles et al. (2004), Grosicki and Rachubik (2005), Afriyie-Gyawu et al. (2005), Alexopoulos et al. (2007), Miles and Henry (2007) and Eleroğlu and Yalçın (2012). However, there is no similarity with the findings of Şehu et al. (2005) and Başalan et al. (2005).

\section{Feed Conversion Ratio}

The highest feed conversion ratio value was obtained for group III at 21.56, followed by group IV at 21.50, group II at 20.08, and group I at 18.70. Our FCR results were similar to the findings of Mayura et al. (1998), Malagutti et al. (2002), Wiles et al. (2004), Forouzani et al. (2004), Afriyie-Gyawu et al. (2005), Sherwood et al. (2005), Başalan et al. (2005), Eraslan et al. (2005), Bailey et al. (2006), Şehu et al. (2007), Miles and Henry (2007), However, our FCR results were not similar to Toker and Köknaroğlu (2004), Deligiannis (2005) and Alexopoulos et al. (2007). When diet clinoptilolite levels increased, in order to get enough nutrients animals consumed more feed. So, additional clinoptilolite levels increased feed conversion ratios.

\section{Hair follicles in skin}

There was a remarkable increase in the diameters of primary and secondary hair follicles in the rat skin. By group, average follicle values obtained are presented in Table 3. The primary and secondary follicle numbers were not statistically significant $(\mathrm{P}>0.05)$, but the diameters of each follicle were found to be significant $(\mathrm{P}<0.05)$. The highest primary follicle number of 2.33 
was obtained from group II and IV, but the lowest, 2.00, was obtained for the control group; the highest primary follicle diameter $(20.42 \mu \mathrm{m})$ was measured in group IV and the lowest was $11.53 \mu \mathrm{m}$, from the control group. The highest secondary follicle number (7.17) was obtained from group II, but the lowest, 4.50, was measured in the control group; the highest secondary follicle diameter $(102.12 \mu \mathrm{m})$ was from group IV and the lowest (57.63 $\mu \mathrm{m})$ was from the control group. Our results are similar to those of Çolpan and Yalçın (1986) pointed out that zeolites improved the hair quality of lambs. In contrast, Murray et al. (1992) found that the inclusion of bentonite in the diet had no effect on wool growth. However, there is no literature addressing the effect of dietary clinoptilolite on follicle numbers and diameters in any animal species.

There is limited information about the effects of dietary zeolite on the quality of wool, fur, angora, etc. in previous studies. These studies have found that zeolites contain $\mathrm{Ca}, \mathrm{P}$, and $\mathrm{Si}$, so if the zeolite supplementation in animal diets is insufficient, the mineral content of fibre is insufficient (Utkanlar and Örkiz, 1960). The supplementation of urea-containing diets with $2.5 \%, 5.0 \%$ and $7.5 \%$ zeolites did not negatively affect wool quality parameters; breaking strength and elasticity were affected positively; and the staple length and leaf diameters were not affected in male merino-bred lambs (Çolpan and Yalçın, 1986).

In the light of our knowledge, there is no literature on the effects of clinoptilolite on primary and secondary follicle numbers and diameters. Potantial reason of increasing follicle diameters especially in group IV, may be mineral content of used clinoptilolite.

\section{Histological changes in skin}

The histological structures of the hair follicles were examined with respect to epidermis, dermis, and epidermal formations in the skin samples in the control group. The most superficial layer of the epidermis, the stratum corneum layer, was observed to have a normal keratinisation appearance (Pic. 1A, B, C). The structure of the epidermis was regular and the stratum papillary layer of the dermis had a loose structure.
In the group II animals ( $2 \%$ clinoptilolite), compared to the controls, in proportion to increasing doses of clinoptilolite, there was an increase in skin keratinizing (stratum corneum) and epidermal thickness (Pic. 2A, B, $\mathrm{C})$. There was a remarkable increase in collagen yarns and the number of primary and secondary hair follicles. However, the histological appearance of the hair follicles was the same as that of the control group.

Additionally, the group III and IV animals, fed diets containing clinoptilolite (4\% and 6\%), presented a remarkable increase in the collagen layers of the yarns dermis str. papillary and str. retikülare (Pic. 3B, C), and the number and diameter of hair follicles and fat glands of secondary hair follicles were increased in volume (Pic. $3 \mathrm{~A}, \mathrm{~B}, \mathrm{C})$.

When we compared group IV with the other groups, the marked fibroblasts can be explained by an increase in collagen synthesis (Pic. 4B, C). There was a remarkable increase in the number and diameter of primary and secondary hair follicles (Pic. 4A, B, C).

There were no marked changes in skin histology in this trial with the use of different clinoptilolite levels. However, there were marked fibroblasts in group IV, and this is the reason of increased collagen synthesis. Marked increase in primary and secondary hair follicle numbers and diameters were led to increase in skin quality. The supplemented clinoptilolite levels were low, and these levels did not cause different results for the skin histology. In addition, it is thought that there were mycotoxins in animal feed and that a lack of mycotoxins can cause such results. According to this study, clinoptilolite is inert and our highest dose $(6 \%)$ is not toxic to animals. No scientific articles were found on the histological changes in any animal skin depending on clinoptilolite application.

Histological changes in liver

A histological examination of liver tissues of the control group showed that the vena sentralis had a normal appearance, and the sequences of hepatocytes (remark cell cords) were found to be regular (Pic.5A). To show the status of liver collagen fibres, Masson's triple staining of the liver and portal area and other areas of collagen staining revealed a normal distribution (Pic. 5B).

Table 2 Total live weight gain, feed intake and feed conversion ratios.

\begin{tabular}{l|ccc}
\hline Treatments & LWG $(\mathrm{g})$ & FI $(\mathrm{g})$ & FCR \\
\hline I (Control) & $53.00 \pm 12.42$ & $988.75 \pm 21.90$ & $18.70 \pm 1.01$ \\
II (2\% zeolite) & $49.75 \pm 9.64$ & $998.58 \pm 20.71$ & $20.08 \pm 1.34$ \\
III (4\% zeolite) & $47.67 \pm 13.79$ & $1011.58 \pm 10.07$ & $21.56 \pm 3.40$ \\
IV (6\% zeolite) & $45.92 \pm 11.11$ & $971.83 \pm 34.89$ & $21.50 \pm 3.17$ \\
P & 0.189 & 0.089 & 0.219 \\
\hline
\end{tabular}

Table 3 Average hair follicle numbers and diameters (micrometer $=\mu \mathrm{m}$ ) according to treatments.

\begin{tabular}{l|cccc}
\hline \multirow{2}{*}{ Groups } & \multicolumn{2}{|c}{ Primary Follicle } & \multicolumn{2}{c}{ Secondary Follicle } \\
& Number & Diameter & Number & Diameter \\
\hline I (Control) & $2.00 \pm 0.45$ & $11.53 \pm 2.35 \mathrm{a}$ & $4.50 \pm 0.99$ & $57.63 \pm 11.77 \mathrm{a}$ \\
II (2\% zeolite) & $2.33 \pm 0.21$ & $13.86 \pm 0.68 \mathrm{a}$ & $7.17 \pm 0.48$ & $69.30 \pm 3.38 \mathrm{a}$ \\
III (4\% zeolite ) & $2.17 \pm 0.48$ & $13.75 \pm 2.83 \mathrm{a}$ & $6.00 \pm 0.73$ & $68.76 \pm 14.13 \mathrm{a}$ \\
IV (6\% zeolite ) & $2.33 \pm 0.33$ & $20.42 \pm 1.90 \mathrm{~b}$ & $6.17 \pm 0.31$ & $102.12 \pm 9.52 \mathrm{~b}$ \\
P & 0.912 & 0.039 & 0.078 & 0.039 \\
\hline a,b Within each column, means superscript with the same letter are not significantly different, $\mathrm{P}<0.05$.
\end{tabular}




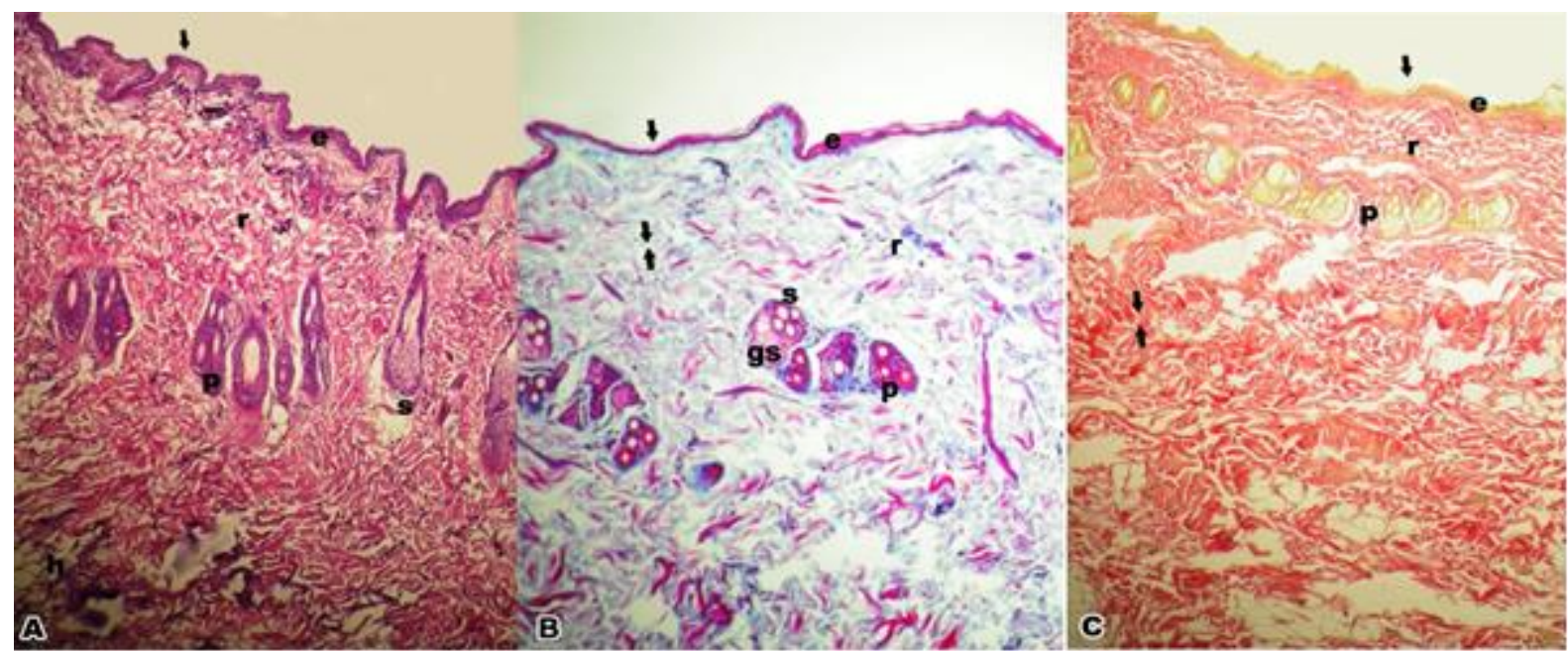

Pic. 1 Histological appearance of the skin in control group (Group I).

A: Stain: Hematoxilen Eozin x 25; B: Stain: Triple x 25; C: Stain: Hematoxilen Van-Gieson x 25. single arrow: keratinization, e: epidermis, r: dermis, double arrow: collagen, p: primary hair follicle, s: secondary hair follicle, gs: glandular sebase, h: hypodermis.

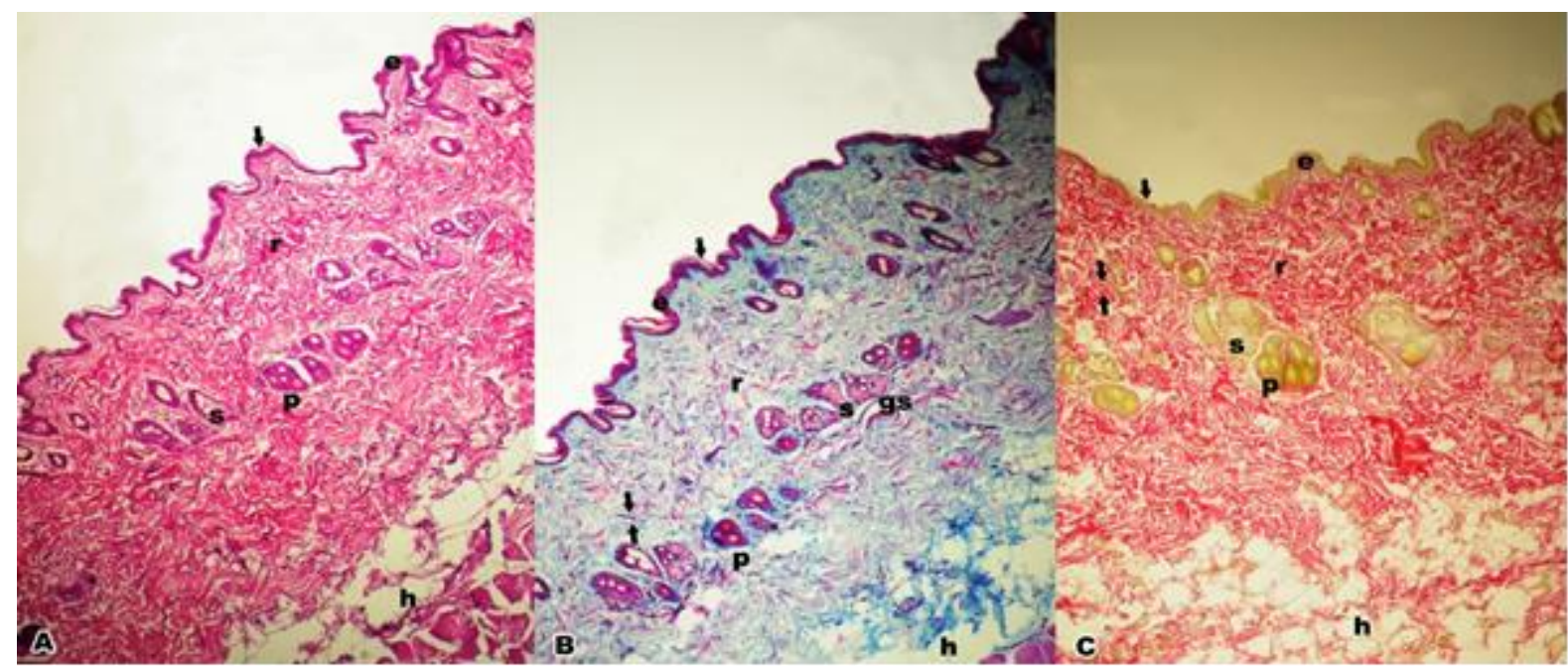

Pic. 2 Histological appearance of the skin in Group II.

A: Stain: Hematoxilen - Eozin x 25; B: Stain: Triple x 25; C: Stain: Hematoxilen Van-Gieson x 25. single arrow: keratinization, e: epidermis, r: dermis, double arrow: collagen, p: primary hair follicle, s: secondary hair follicle, gs: glandular sebase, h: hypodermis.

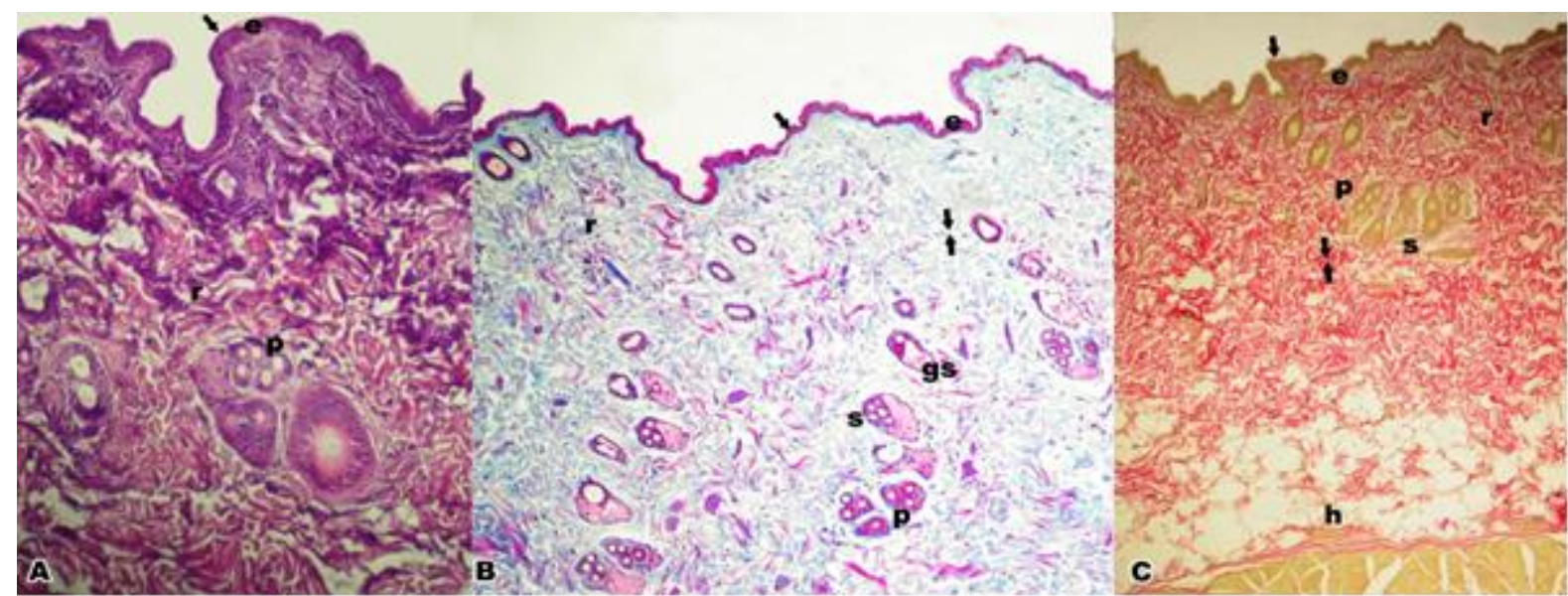

Pic. 3 Histological appearance of the skin of rats in Group III.

A:Stain: Hematoxilen Eozin x 80; B: Stain: Triple x 25; C: Stain: Hematoxilen Van-Gieson x 25. single arrow: keratinization, e: epidermis, r: dermis, double arrow: collagen, p: primary hair follicle, s: secondary hair follicle, gs: glandular sebase, h: hypodermis. 


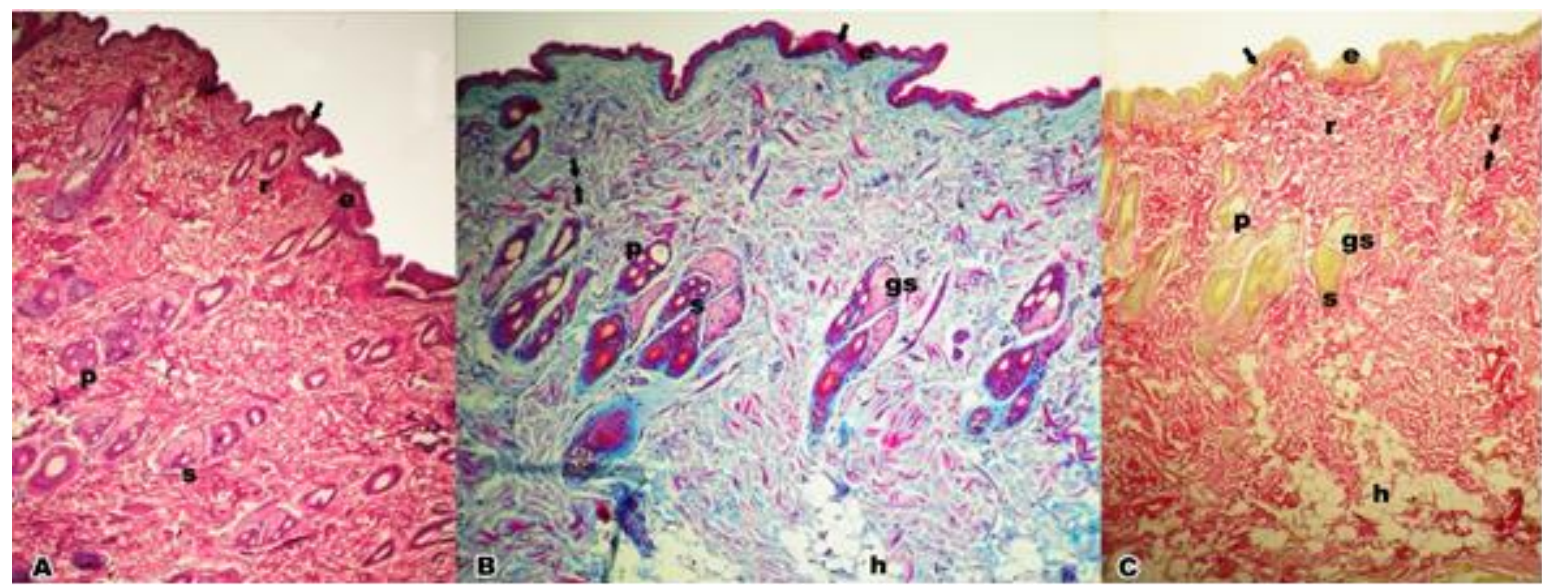

Pic. 4 Histological appearance of the skin in Group IV.

A: Stain: Hematoxilen Eozin x 25; B: Stain: Triple x 25; C: Stain: Hematoxilen Van-Gieson x 25. Single arrow: keratinisation, e: epidermis, r: dermis, double arrow: collagen, p: primary hair follicle, s: secondary hair follicle, gs: glandular sebase, h: hypodermis.

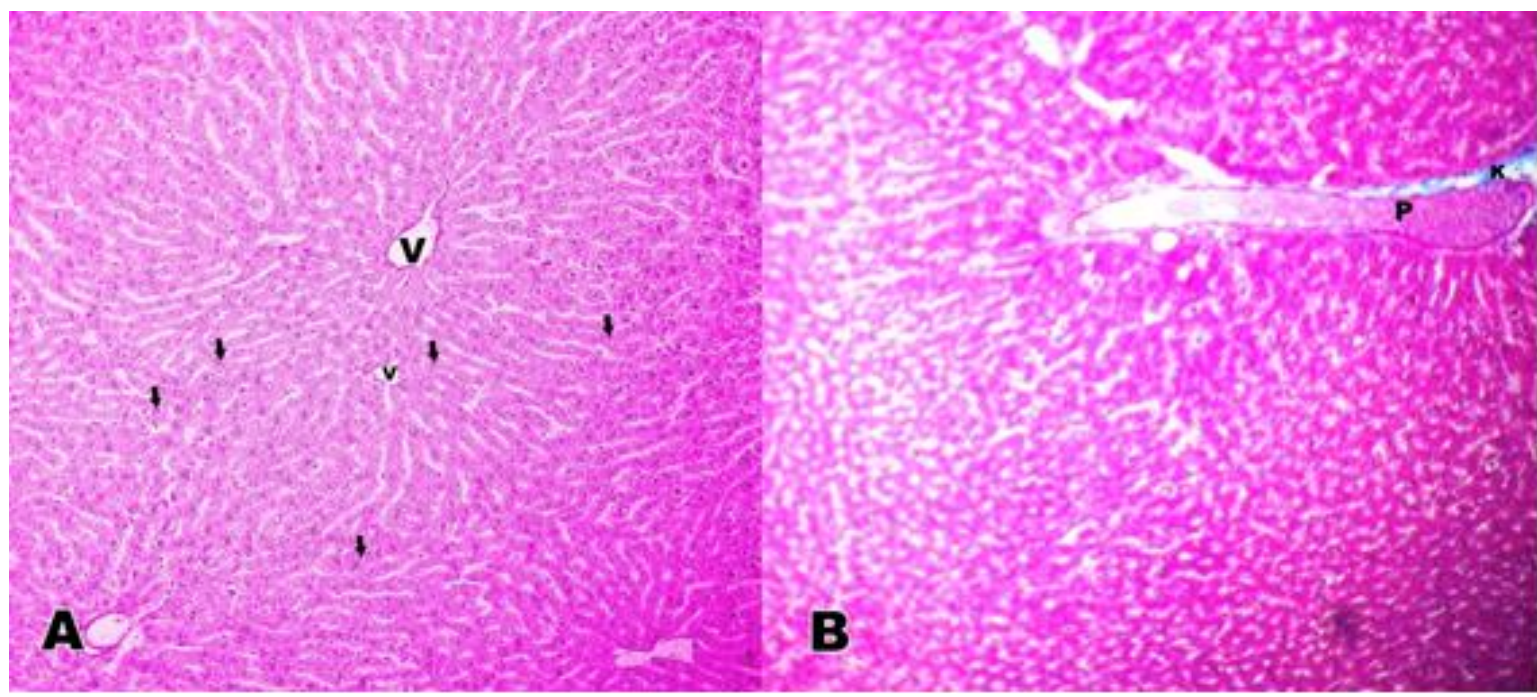

Pic. 5 Histological appearance of the liver in control group (Group I).

A: Stain: Hematoxilen Eozin x 25; B: Stain: Triple x 80, v: Vena sentralis, s: sinusoid, arrows: hepatocytes, p: portal space, k: collagen.

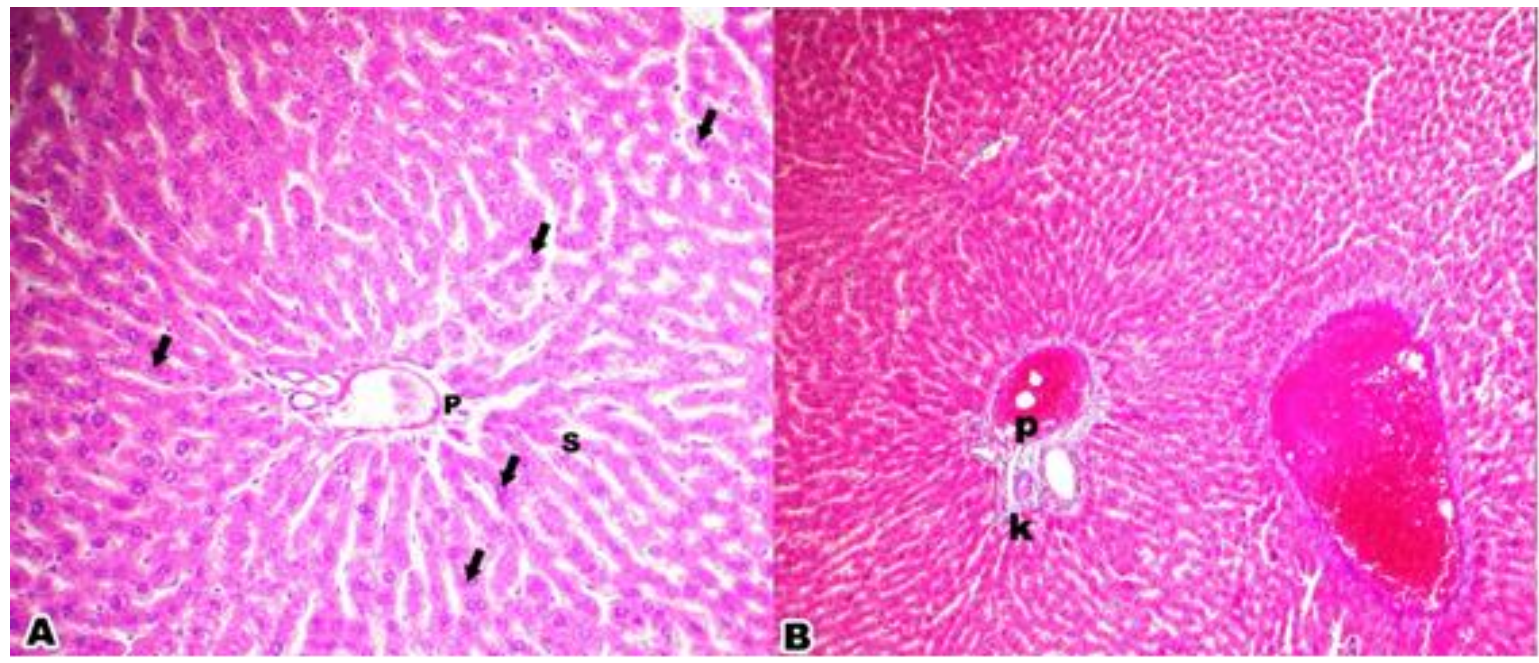

Pic. 6 Histological appearance of the liver in Group II.

A: Stain: Hematoxilen Eozin x 80; B: Stain: Triple x 25, s: sinusoid, arrows: hepatocytes, p: portal space, k: collagen. 
The nontoxic effect of the clinoptilolite dose and type on skin and liver tissues was similar to those of previous studies: in pig diets, $2 \%$ additional clinoptilolite did not affect the vitamin and mineral content in the liver and kidneys (Papaioannou et al., 2002); in mouse diets, $5 \mathrm{~g} / \mathrm{kg}$ HSCAS (Abbès, 2006a) and montmorillonite did not affect the liver and kidney histology (Abdel-Wahhab, 2002), 400, 600, and $800 \mathrm{mg} / \mathrm{kg}$ HSCAS on spleen histology (Abbès, 2006b); in pregnant rat diets, 0.5\% HSCAS on liver and kidney histology (Mayura et al., 1998); in quail diets $0.5 \%$ HSCAS (Şehu et al., 2007) and $0.25-0.50 \% \mathrm{Na}$ bentonite (Eraslan et al., 2006) on liver pathology. These findings were parallel with the results of our study, as clinoptilolite did not affect the liver and skin histology. There were no remarkable histological changes in the liver tissue of rats supplemented with different clinoptilolite levels in their diets (Pic. 6A, B; 7A, B; 8A, B).

The reason of this may be low dietary mycotoxin levels can not demage skin and liver tissue structure. In all groups, the hepatocytes, vena sentralis, and sinusoidal structures had a normal appearance, depending on the zeolite application in routine hematoxylin-eosin staining. In addition, zeolite application did not lead to increased liver tissue collagen according to Masson triple staining. Intracytoplasmic fat accumulation and different degeneration of liver cells were not observed.

\section{Conclusion}

The results of this study indicate that the dietary use of clinoptilolite at the inclusion rates of $2 \%, 4 \%$, and $6 \%$ did not cause any adverse effects on the health status and histological appearance of the skin and liver tissues of rats. Mycotoxin-contaminated feed ingredients can change skin and liver tissues. In addition, the dietary use of clinoptilolite increased the diameters of primary and secondary follicles in the skin. Stability in skin and liver tissue may be lower levels of used clinoptilolite in rat diets. In addition, increasing hair diameter decreases wool quality because of the increasing hair medulla. Thus, it can be said that higher levels of clinoptilolite $(6 \%)$ can cause lower-quality animal fibres. Increasing primary and secondary hair follicle diameters may lead to decreased wool, angora, and fur quality. There is a negative relationship between hair diameter and quality. At the same time, a strong follicle structure may lead to strong, healthy hair in animal and people. Animal fibre (wool, angora, fur, etc.) quality is very important in the textile industry. When fibre thickness decreases, the product quality increases. There is not enough literature about the effect of clinoptilolite on animal fibre quality. In further studies, effect of clinoptilolite on textile quality fibre containing animals (especially with sheep, angora, fur animals etc.) should be investigated more detailed.

There was a positive effect of $6 \%$ clinoptilolite on the liver and skin histology. There is a need to investigate the trace minerals in clinoptilolite structures and their synergetic or antagonistic relationships so that detailed results can be obtained regarding mineral metabolism. Higher clinoptilolite doses and mycotoxin levels can be examined in animal diets in future research studies.

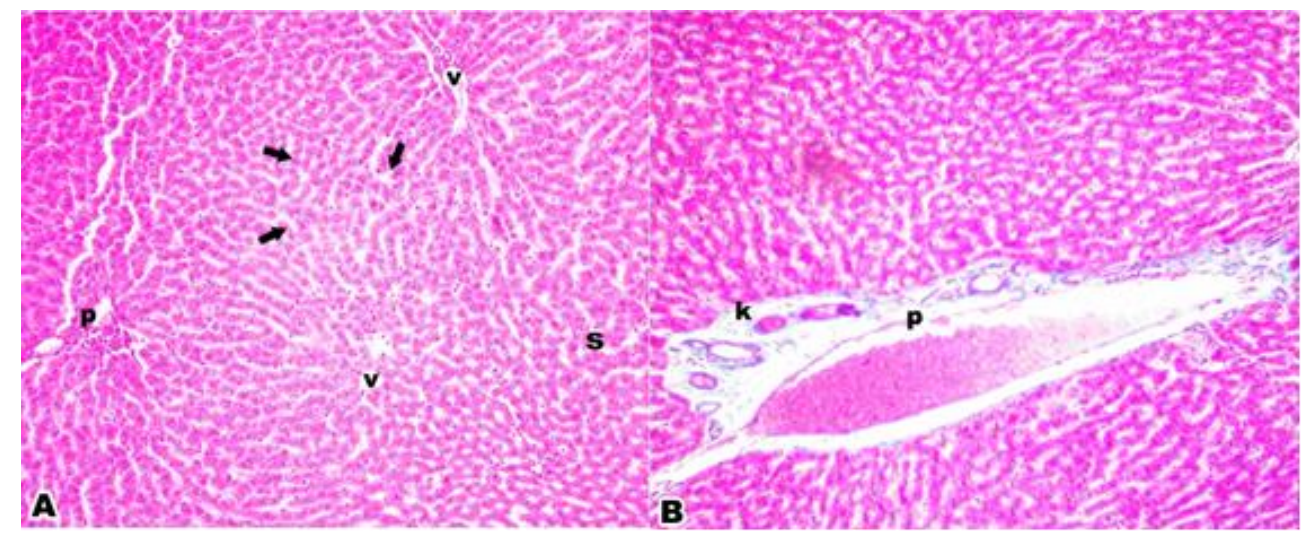

Pic. 7 Histological appearance of the liver in Group III.

A: Stain: Hematoxilen Eozin x 25; B: Stain: Triple x 80. v: Vena sentralis s: sinusoid, arrows: hepatocytes, p: portal space, k: collagen.

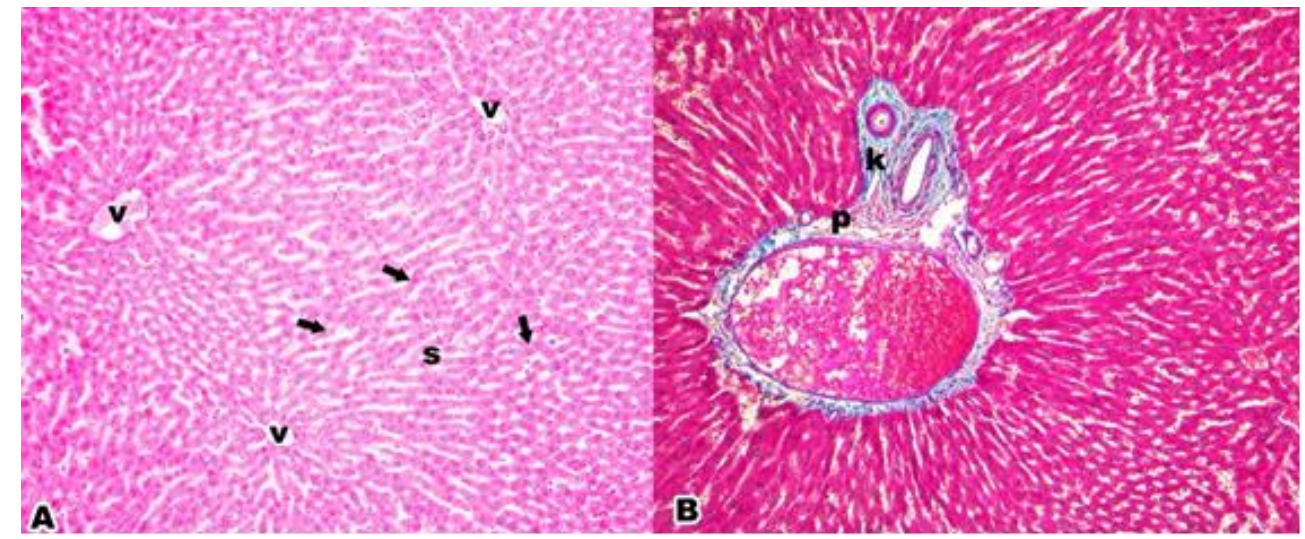

Pic. 8 Histological appearance of the liver in Group IV.

A: Stain: Hematoxilen Eozin x 25; B: Stain: Triple x 80. v: Vena sentralis s: sinusoid, arrows: hepatocytes, p: portal space, k: collagen. 


\section{Acknowledgement}

The authors are grateful to the Scientific Research Project Fund of the Dicle University (DUAPK) under the project number grant - 05-ZF-36 for their financial support and Rota Mining Corp. firm for clinoptilolite supply.

\section{References}

Abbès S, Quannes Z, Salah-Abbès JB, Houas Z, Queslati R, Bacha H, Othman O. 2006a. The protective effect of hydrated sodium calcium aluminosilicate against haematological, biochemical and pathological changes induced by zearalenone in mice. Toxicon. 47: 567-574.

Abbès S, Salah-Abbès JB, Quannes Z, Houas Z, Othman $\mathrm{O}$, Bacha H, Abdel-Wahhab MA, Queslati R. 2006b. Preventive role of phyllosilicate clay on the immunological and biochemical toxicity of zearalenone in balb/c mice. Int Immunopharm. 6: 1251-1258.

Abdel-Wahhab MA, Nada SA, Khalil FA. 2002. Physiological and toxicological responses in rats fed aflatoxincontaminated diet with or without sorbent materials. Anim. Feed. Sci. Tech. 97: 209-219.

Afriyie-Gyawu E, Mackie J, Bhagirathi D, Wiles M, Taylor J, Huebner H, Tang L, Guan H, Wang JS, Phillips T. 2005. Chronic toxicological evaluation of dietary Novasil clay in Sprague-Dawley rats. Food Addit. Contam. 22: 259-269.

Alexopoulos C, Papaioannou DS, Fortomaris P, Kyriakis CS, Tserveni-Goussi A, Yannakopoulos A, Kyriakis SC, 2007. Experimental study on the effect of in feed administration of a clinoptilolite-rich tuff on certain biochemical and hematological parameters of growing and fattening pigs. Livest. Sci. 111: 230-241.

Anonymous. 2012. "Rotamin" Feed Additive. Rota Mineral Corporation. http:// www. zeoliteproducer.com /rotamintr.html. Accesed 11 January 2012.

Bailey CA, Latimer GW, Barr AC, Wigle WL, Haq AU, Balthrop JE, Kubena LF. 2006. Efficacy of montmorillonite clay (NovaSil PLUS) for protecting full-term broilers from aflatoxicosis. J. Appl. Poultry. Res. 15: 198-206.

Başalan M, Güngör T, Aydoğan I, Hışmığulları SE, Erat S, Erdem E. 2005. Effects of adding HSCAS to broiler diets prior to slaughter on performance, digestive system $\mathrm{pH}$ 's and blood biochemistry. National Animal Nutrition Congress III. September 7-10, p: 374-377. Adana.

Cobon DH, Stephenson RGA, Hopkins PS. 1992. The effect of oral administration of methionine, bentonite, methionine/ bentonite and methionine/ oil homogenates on wool production of grazing and penned sheep in a semi-arid tropical environment. Aust. J. Exp. Agr. 32: 435-441.

Çolpan I, Yalçın S. 1986. Effects of dietary zeolite on wool characters in merino bred lambs. Reprint: Journal of Ankara. Üniv. Vet. Fac. 33: 261-272.

Deligiannis K, Lainas TH, Arsenos G, Papadopoulos E, Fortomaris P, Kufidis D, Stamataris C, Zygoyiannis D. 2005. The effect of feeding clinoptilolite on food intake and performance of growing lambs infected or not with gastrointestinal nematodes. Livest. Prod. Sci. 96: 195-203.

Demir R, Y1lmazer S, Öztürk M, Üstünel I, Demir N, Korgun ET, Akkoyunlu G. 2001. Reference book for histological staining techniques. In: General methods of histologic examination of tissues. Demir, R. (ed.). Ankara, Palme Publishing, First Edition. p, 54-80.

Demirel R, Yokuş B, Şentürk Demirel D, Ketani MA, Baran M S. 2011. Effects of dietary zeolite on serum contents and feeding performance in rats. Int. J. Agric. Biol., 13: 346-350.

Duncan DB. 1955. Multiple range and multiple f-tests. Biometrics. 11: 1-42.
Eleroğlu H, Yalçın H, Yıldırım A. 2011. Dietary effects of Cazeolite supplementation on some blood and tibial bone characteristics of broilers. S. Afr. J. of Anim. Sci. 41: 319-330.

Eleroğlu H, Yalçın H. 2012. Dietary effects of Ca-Zeolite supplementation on water consumption and carcass caracteristics of broilers. J. of Animal and Vet. Advan. 11: 43-51.

Eraslan G, Eşsiz D, Akdoğan M, Şahindokuyucu F, Altıntaş L. 2005. The effects of aflatoxin and sodium bentonit combined and alone on some blood electrolyte levels in broiler chickens. Turk J Vet Anim Sci, 29, 601-605.

Eraslan G, Eşsiz D, Akdoğan M, Karaöz E, Öncü M. Özyıldız Z. 2006. Efficacy of dietary sodium bentonit against subchronic exposure to dietary aflatoxin in broilers. Bull. Vet. Inst. Pulawy. 50: 107-112.

Forouzani R, Rowghani E, Zamiri MJ. 2004. The effect of zeolite on digestibility and feedlot performance of Mehraban male lambs given a diet containing urea-treated maize silage. Anim. Sci, 78: 179-184.

Grosicki A, Domanska K. 2000. Use of bentonite to affect cadmium toxicokinetics. Mengen-und Spurenelemente 20. Arbeitstagung, 609-614.

Grosicki A, Rachubik J. 2005. Influence of bentonite on trace element kinetics in rats. III. Selenium. Bull. Vet. Inst. Pulawy. 121-123.

Katsoulos PD, Panousis N, Roubies N, Christaki E, Arsenos G, Karatzias H. 2006. Effects of long-term feeding of a diet supplemented with clinoptilolite to dairy cows on the incidence of ketosis, milk yield and liver function. Vet. Rec. 159: 415-418.

Malagutti L, Zannotti M, Sciaraffia F. 2002. Use of clinoptilolite in piglet diets as a substitute for colistine. Ital. J. Anim. Sci. 1: 275-280.

Mayura K, Abdel-Wahhab MA, Mckenzie KS, Sarr AB, Edwards JF, Naguib K, Phillips TD. 1998. Prevention of maternal and developmental toxicity in rats via dietary inclusion of common aflatoxin sorbents: potential for hidden risks. Tox Sci. 41: 175-182.

Melenova L, Ciahotny K, Jirglova H, Kusa H, Ruzek P. 2003. Removal of ammonia from waste gas by means of adsorption on zeolites and their subsequent use in agriculture (in czech). Chem Listy. 97: 562-568.

Miles RD, Henry PR, 2007. Safety of improved Milbond-TX ${ }^{\circledR}$ when fed in broilers diets at greater than recommended levels. Anim. Feed Sci. Tech. 138: 309-317.

Mumpton FA. 1999. La roca magica: Uses of natural zeolites in agriculture and industry. Proc. Natl. Acad. Sci., USA. 96: 3463-3470.

Murray PJ, Winslow SG, Rowe JB. 1992. Effect of dry or hydrated bentonite on the wool growth and liveweight gain of sheep fed wheat chaff. Aust. J. Exp. Agr. 32: 595-600.

Papaioannou DS, Kyriakis SC, Papasteriadis A, Roumbies N, Yannakopoulos A, Alexopoulas C. 2002. Effect of in-feed inclusion of a natural zeolite (clinoptilolite) on certain vitamin, macro and trace element concentrations in the blood, liver and kidney tissues of sows. Res Vet. Sci. 72: 61-68.

Papaioannou DS, Kyriakis CS, Alexopoulas C, Tzika ED, Polizopoulou ZS, Kyriakis SC. 2004. A field study on the effect of dietary use of a clinoptilolite-rich tuff, alone or in combination with certain antimicrobials, on the health status and performance of weaned, growing and finishing pigs. Res. Vet. Sci. 76: 19-29.

Pond WG, Yen JT, Varel VH. 1988. Response of growing swine to dietary copper and clinoptilolite supplementation. Nutr. Rep. Int. 37: 797-803.

Prvulović D, Jovanović - Galović A, Stanić B, Popović M, Grubor-Lajšić G, 2007. Effects of clinoptilolite supplement in pig diets on performance and serum parameters. Czech. J. Anim. Sci. 52: 159-64. 
Sorokina EIU, Levitskaia AB, Aksiuk IN. 1995. Study of long term effects of zeolites on the body of laboratory animals. Vopr. Pitan. 3: 16-18.

SPSS Inc. 1999. SPSS Base 10.0 for Windows User's Guide SPSS Inc. Chicago IL.

Şehu A, Çakır S, Eşsiz D, Ergün L. 2005. Preventive effects of HSCAS (Improved milbond-TX ${ }^{\circledR}$ ) on aflatoxicosis symptoms in quails (coturnix coturnix japonica). National Animal Nutrition Congress III, September 7-10, Adana. P: 374-377.

Şehu A, Ergün L, Çakır S, Ergün E, Cantekin Z, Şahin T, Eşsiz D, Sareyyüpoğlu B, Gürel Y, Yiğit Y. 2007. Hydrated sodium calcium aluminosilicate for reduction of aflatoxin in quails (coturnix coturnix japonica). Deut. T1erarztl. Woch. 114: 144-151.

Sherwood DM, Erickson GE, Klopfenstein TJ. 2005. Effect of Clinoptilolite Zeolite on Cattle Performance and Nitrogen Volatilization Loss. Nebraska Beef Report, 76.

Taş M, Demirel R, Şentürk Demirel D, Kurt D, Bacinoğlu S, Cirit Ü, Ketani MA. 2007. Effects of dietary natural zeolite on the testicular weight, body weight and spermatological characteristics in rats. J. Istanbul Univ. Fac. Vet. Med. 33: 33-42.
Toker TM, Köknaroğlu H. 2004. Zeolitin ve Besi Baş1 Ağırlığının İsviçre Esmeri Danaların Feedlot Performansı Üzerine Etkileri. 4. Ulusal Zootekni Bilim kongresi, 1-3 Eylül 2004, 405-409, Isparta.

Trckova M, Matlova L, Dvorska L, Pavlik I. 2004. Kaolin, bentonit, and zeolites as feed supplements for animals: health advantages and risks. Vet. Med. 49: 389-399.

Utkanlar N, Örkiz M.1960. Factors that affect the yield on the quality of fleece. Journal of Lalahan Livestock Research Institute. 40-51.

Walz LS, White TW, Fernandez JM, Gentry LR, Blouin DC, Froetschel MA, Brown TF, Lupton CJ, Chapa AM. 1998. Effects of fish meal and sodium bentonite on daily gain, wool growth, carcass characteristics, and ruminal and blood characteristics of lambs fed concentrate diets. J. Anim. Sci. 76: 2025-2031.

Wiles MC, Huebner HJ, Afriyie-Gyawu E, Taylor TJ, Bratton GR, Phillips TD. 2004. Toxicological evaluation and metal bioavability in pregnant rats following exposure to clay minerals in the diet. J. Toxicol. Environ. Health, Part A, 67: 863-874. 